Article

\title{
Sustainability Reporting and Performance Measurement Systems: How do Small- and Medium- Sized Benefit Corporations Manage Integration?
}

\author{
Giorgia Nigri $^{1, *(\mathbb{D})}$ and Mara Del Baldo ${ }^{2}$ \\ 1 Department of Economics, LUMSA University, Via Pompeo Magno 22, 00192 Rome, Italy \\ 2 Department of Economics, Society, Politics, Urbino University, Via Saffi 42, 61029 Urbino, Iatly; \\ mara.delbaldo@uniurb.it \\ * Correspondence: g.nigri@lumsa.it; Tel.: +39-3484987966
}

Received: 16 October 2018; Accepted: 26 November 2018; Published: 29 November 2018

\begin{abstract}
Benefit Corporations and B Corps represent alternative models of enterprise, often referred to as "hybrid companies" that bridge the for-profit and not-for-profit models. Italy is the first country outside the USA to pass Benefit Corporation legislation and introduce the Società Benefit. A large number of Italian Benefit Corporations are small- and medium-sized companies (SMEs), since SMEs are widespread within the entrepreneurial fabric and have great relevance in the Italian socio-economic context. A key issue in the emerging debate on small- and medium-sized Benefit Corporations concerns how these companies-with limited reach and considerable financial and human resource constraints—can effectively absorb their added social responsibility. In particular, such firms need to manage their dual mission, integrate social and environmental goals in their business model, and incorporate accountability mechanisms, all while scaling up and garnering the necessary resources to be economically competitive. Starting from these premises, this paper focuses on the performance measurement and reporting systems that are adopted by SMEs that are also Benefit Corporations, and investigates whether benefit impact assessment indicators integrate into an overall sustainability performance management system. To achieve this goal, an exploratory case-based analysis on seven small- and medium-sized Italian-certified Benefit Corporations is presented.
\end{abstract}

Keywords: Benefit Corporations; B Corps; corporate social responsibility reporting; sustainable management accounting systems; sustainable performance management systems; small and medium enterprise

\section{Introduction}

Integrating sustainability indicators into daily decision-making is a fundamental element of sustainability performance management systems (SPMS). Defined as the process of identifying social, environmental, and economic drivers that influence the success of an organization and measuring progress against those drivers [1], SPMS has been regarded as the best way to capture the complexity of the triple bottom line framework (TBL) [2,3].

Sustainability is now seen as the business paradigm for the 21st century. Decisions regarding corporate sustainability pose a significant dilemma for managers: to weigh social and environmental concerns against economic results [4]. Pursuing missions that differ from shareholder value maximization poses an even stronger need for all those forms of hybrid organizations, where the focus is on multiple bottom lines, to monitor and measure the extra value created. Measuring social impact takes on a pivotal role in this type of organization, since social value makes traditional 
reporting unsuitable for organizations with a social purpose to prove their benefits for society [5-8]. Indeed, focusing on economic and financial results leads to a misrepresentation of the more far-reaching impact that socially purposed organizations can create (and destroy) for society [7,9-11]. This is particularly true for hybrid companies such as Benefit Corporations.

Benefit Corporations or B Corps have been recognized by legislation in the USA and Italy [12], or certified by B Lab, a non-profit organization that measures public benefit through a third-party standard [13-15]. In the first case (Benefit Corporations), there is a structured legal framework and an obligation to draw up an annual report, while in the second case (B Corps), the company is assessed by the benefit impact assessment (BIA), a tool through which a company discloses the impact of its actions on the environment, workers, communities, customers, and business model [16]. Due to their reinforced commitment to corporate social responsibility (CSR) practices and a mission bound to generate a public benefit, such organizations are a clear example of the convergence of for-profit companies and a strong CSR focus [17-21].

In this scenario, McMullen and Warnick [22] underline a one-size-fits-all approach, and Stubbs (2017) identified the relevant, vital themes to analyze their business model (mainly principal objectives, measuring success, stakeholders, and influencing the sustainability agenda).

While many authors have contributed with conceptual frameworks to better understand and integrate sustainability performance (SP) into business with specific figures and unique measurement methods, building a comprehensive measure of performance and developing instruments to manage multiple objectives is still a significant challenge [2,23-25] given the multiperspective character of sustainability and the variety of goals and stakeholders involved [26].

This paper aims to extend the comprehension of SPMS by exploring the level of integration of benefit impact assessment indicators into Benefit Corporation measurement, management, and reporting systems. More specifically, the research seeks to address whether Benefit Corporations have set the basis for a truly integrated overall sustainability performance management system guided by a single measure- - the Benefit Impact Assessment.

\section{Theoretical Background}

\subsection{Correlation between Corporate Social Responsibility Reporting and Performance and Management Accounting Systems}

Two critical factors emerge when analyzing the management of CSR reporting: the level of formalization and the level of integration into the day-to-day sustainability management [3]. For sustainability practices to work, it is essential for SP to integrate the essence of sustainability into daily decision-making and accountability processes, including sustainability reporting [27-29]. Sustainability should be disseminated into every business process throughout the organization $[2,26,30-33]$.

Multicriteria decision theory is suggested in the literature as being appropriate to orchestrate the multiple pieces of knowledge relating to sustainability [34] and to support sustainability decisions [35-37]. So far, though, proposals have not provided a single balanced measure that captures the complexity of the TBL and integrates it into management control systems (MCSs) [2]. Most strikingly, findings indicate that different management practices lead to similar outcomes [3], and aggregation plays a significant role in extracting useful information from data and communicating it to stakeholders as a sole measure [35].

The body of knowledge regarding performance measurement, management accounting systems, and corporate social responsibility is vast [38-40]. To make sense of the literature, the correlations among the various research topics were analyzed and summarized in a table. Tables 1 and 2 introduce the contributions that examine the relations between sustainability and performance management and highlight the ties among corporate social responsibility, sustainability performance, and management accounting approaches. Synergies are found when studying the tools and instruments that are used to measure, manage, and report sustainability and regular business processes [41-43], such as 
sustainability balance scorecards and performance measurement system indicators. For example, if we look at the intersection in Table 1 between CSR measurement and SP reporting, we find that by disclosing sustainability information, companies aim in fact to increase transparency; enhance brand value, reputation, and legitimacy; enable benchmarking against competitors; signal competitiveness; motivate employees; and support corporate information and control processes.

Table 1. Publications focused on the correlations among corporate social responsibility, sustainability performance, and management accounting measurement, management, and reporting approaches.

\begin{tabular}{|c|c|c|c|}
\hline & \multicolumn{3}{|c|}{ Sustainability Performance } \\
\hline $\begin{array}{c}\text { Corporate Social } \\
\text { Responsibility }\end{array}$ & Measurement & Management & Reporting \\
\hline $\begin{array}{c}\text { Social Impact } \\
\text { Assessment }\end{array}$ & $\begin{array}{l}\text { Social impact assessment (SIA) } \\
\text { models include the Social } \\
\text { Return On Investment, the } \\
\text { Social Accounting and Audit, } \\
\text { and the Global Reporting } \\
\text { Initiative }[9,44-46] \text {. }\end{array}$ & $\begin{array}{l}\text { SIA has important benefits for } \\
\text { organizations, both as a } \\
\text { management tool, enabling a } \\
\text { deep understanding of how } \\
\text { best to allocate resources to } \\
\text { maximize social outcomes [47], } \\
\text { and to assess if the } \\
\text { organization is achieving its } \\
\text { targeted social mission [48]. }\end{array}$ & $\begin{array}{l}\text { The main reasons for } \\
\text { companies to publish a } \\
\text { sustainability report (SR) are } \\
\text { to communicate with } \\
\text { stakeholders about } \\
\text { non-market issues; to secure or } \\
\text { increase legitimacy, credibility, } \\
\text { and corporate reputation; and } \\
\text { to motivate employees to deal } \\
\text { with sustainability issues and } \\
\text { benchmarking [49-52]. }\end{array}$ \\
\hline Measurement & $\begin{array}{l}\text { The role of performance } \\
\text { management systems (PMSs) } \\
\text { is to enable the definition of } \\
\text { objectives to be fulfilled by } \\
\text { management towards } \\
\text { sustainability outcomes. This } \\
\text { allows firms to identify critical } \\
\text { areas, define Key Performance } \\
\text { Indicators (KPIs), and } \\
\text { efficiently distribute scarce } \\
\text { resources [53-55]. }\end{array}$ & $\begin{array}{c}\text { For an integrated management } \\
\text { of sustainability issues, } \\
\text { environmental, social, } \\
\text { financial, and risk } \\
\text { performance indicators should } \\
\text { be combined into an overall } \\
\text { performance measurement } \\
\text { system }[26,28,31] .\end{array}$ & $\begin{array}{l}\text { Through SR, companies aim to } \\
\text { enhance transparency, brand } \\
\text { value, reputation, and } \\
\text { legitimacy; enable } \\
\text { benchmarking; signal } \\
\text { competitiveness; motivate } \\
\text { employees; and support } \\
\text { corporate information and } \\
\text { control processes [56-58]. }\end{array}$ \\
\hline Management & $\begin{array}{l}\text { Up to now, SP management } \\
\text { has been mostly related to } \\
\text { environmental performance } \\
\text { management, promoting } \\
\text { initiatives to prevent, mitigate, } \\
\text { or control negative } \\
\text { environmental impacts, and } \\
\text { compliance with } \\
\text { regulation [30]. }\end{array}$ & $\begin{array}{l}\text { SP management encompasses } \\
\text { practices to improve } \\
\text { environmental and social } \\
\text { performance and is related to } \\
\text { management systems, which } \\
\text { can be supported by } \\
\text { consolidated frameworks such } \\
\text { as the European } \\
\text { Eco-Management and Audit } \\
\text { Scheme, ISO1400, OHSAS } \\
\text { 18001, SA8000, and } \\
\text { ISO26000 [59-61]. }\end{array}$ & $\begin{array}{l}\text { The evolution of sustainability } \\
\text { reporting as an endpoint for } \\
\text { any framework for } \\
\text { sustainability performance } \\
\text { management is strongly } \\
\text { influenced by a number of } \\
\text { contingent factors, of which } \\
\text { two stand out: guidance } \\
\text { documents and } \\
\text { quasi-standards such as the } \\
\text { Global Reporting Initiative } \\
\text { (GRI) and International } \\
\text { Integrated Reporting Council, } \\
\text { and reporting, competitions, } \\
\text { and rankings }[62,63] .\end{array}$ \\
\hline Reporting & $\begin{array}{l}\text { Reporting guidelines, such as } \\
\text { GRI, and accountability } \\
\text { approaches can serve as an } \\
\text { input for elaborating an } \\
\text { adequate SP measurement } \\
\text { system for internal } \\
\text { decision-making. SP reporting } \\
\text { addresses how the } \\
\text { performance assessed can be } \\
\text { used to elaborate disclosure } \\
\text { and communicate } \\
\text { performance [64-67]. }\end{array}$ & $\begin{array}{l}\text { Management and reporting of } \\
\text { SP present close connections, } \\
\text { as one can serve as an input } \\
\text { for the other. For instance, } \\
\text { indicators related to social and } \\
\text { environmental practices can be } \\
\text { included as part of the } \\
\text { reporting framework }[68,69] \text {. }\end{array}$ & $\begin{array}{l}\text { Standardization of SR enables } \\
\text { comparison between firms. } \\
\text { The GRI is the leader in the } \\
\text { development of a triple } \\
\text { bottom line (TBL) framework } \\
\text { that enhances the utility of } \\
\text { these publications. SP } \\
\text { reporting is not synonymous } \\
\text { with sustainability accounting, } \\
\text { but contributions can be } \\
\text { complementary [70]. }\end{array}$ \\
\hline
\end{tabular}


In the same way, if we look at the intersection in Table 2 between the CSR measurement and management accounting systems (MAS) tools such as the sustainability balance scorecard (SBSC), we find that the SBSC is an approach that is targeted to improve the integration of environmental, social, and economic aspects of corporate sustainability measurement with management [71]. It focuses the attention of management on key performance measures, including both financial and nonfinancial measures [72].

Table 2. Publications focused on the correlations among corporate social responsibility, management accounting systems, and measurement, management, and reporting approaches.

\begin{tabular}{|c|c|c|}
\hline & \multicolumn{2}{|c|}{ Management Accounting Systems } \\
\hline $\begin{array}{l}\text { Corporate Social } \\
\text { Responsibility }\end{array}$ & $\begin{array}{l}\text { Sustainability Balanced Scorecard } \\
\text { (SBSC) }\end{array}$ & Performance Measurement Systems \\
\hline Social Impact Assessment & $\begin{array}{l}\text { In order for sustainability indicators to } \\
\text { become effective in a company, a } \\
\text { systemic approach such as the SBSC is } \\
\text { required to determine which indicators } \\
\text { are strategically relevant }[32,73] .\end{array}$ & $\begin{array}{l}\text { Today, SIA is applied in many different } \\
\text { settings, and it has become an integral } \\
\text { part of corporate social responsibility } \\
\text { [74]. Scholars have become aware that } \\
\text { social impact measurement tools } \\
\text { (traditionally disseminated to meet } \\
\text { regulatory requirements) could also } \\
\text { measure corporate social responsibility } \\
\text { (CSR) activities [17]. }\end{array}$ \\
\hline Measurement & $\begin{array}{l}\text { The SBSC is an approach that is targeted } \\
\text { to improve the integration of } \\
\text { environmental, social, and economic } \\
\text { aspects of corporate sustainability } \\
\text { measurement and management [71]. It } \\
\text { focuses the attention of management on } \\
\text { key performance measures, including } \\
\text { both financial and nonfinancial } \\
\text { measures [72]. }\end{array}$ & $\begin{array}{l}\text { Considering that corporate PMSs, } \\
\text { indicators, and bonuses may affect their } \\
\text { actions and decision-making [75], any } \\
\text { company aiming to be sustainable must } \\
\text { develop a PMS that can incorporate } \\
\text { sustainability performance measures in } \\
\text { a normatively desirable sustainable } \\
\text { scenario [76,77], creating a series of } \\
\text { aligned consequences. Such a system } \\
\text { may be useful to provide information } \\
\text { for decision-makers, to promote } \\
\text { organizational learning, and to } \\
\text { encourage stakeholder engagement [78]. }\end{array}$ \\
\hline Management & $\begin{array}{l}\text { Once the SBSC, including the strategy } \\
\text { map and the performance indicators, is } \\
\text { developed for the company, the } \\
\text { management challenge is to translate } \\
\text { the strategic considerations into the } \\
\text { information and accounting system in } \\
\text { order to collect the relevant information } \\
\text { to support a successful consideration of } \\
\text { the strategically relevant sustainability } \\
\text { issues [32,79]. }\end{array}$ & $\begin{array}{l}\text { A PMS can influence corporate results, } \\
\text { since it directly impacts managers' } \\
\text { actions and decisions [75]. An SPMS can } \\
\text { be defined as the system of indicators } \\
\text { that provides management with the } \\
\text { necessary information to assist in the } \\
\text { management, control, planning, and } \\
\text { performance of its socio-economic } \\
\text { activities [80]. }\end{array}$ \\
\hline Reporting & $\begin{array}{l}\text { One way to establish links between the } \\
\text { measurement of corporate social and } \\
\text { environmental issues and its business } \\
\text { success is to determine KPIs with the } \\
\text { SBSC and to orientate the accounting } \\
\text { systems towards the provision of the } \\
\text { necessary data for these indicators [26]. }\end{array}$ & $\begin{array}{l}\text { When defining performance indicators, } \\
\text { firms need to consider the purpose of } \\
\text { those indicators, the unit of analysis, } \\
\text { and the level in the organization }[81,82] \\
\text { Firms need to critically analyze their } \\
\text { performance measurement systems, } \\
\text { assessing if they are appropriate for } \\
\text { managing business or if their function is } \\
\text { solely to satisfy stakeholders' needs or } \\
\text { pressures [83-86]. }\end{array}$ \\
\hline
\end{tabular}

The literature points out factors that motivate firms toward sustainability reporting, such as to address an increasing demand for transparency [87], to enhance the corporation's reputation and brand image [81], to influence investor and customer decisions [88-91], to react after negative 
media attention [92], and to follow legal obligations. The most exciting evolution of the literature, however, is the intensification of interest in investigating how SP integrates into business strategy and management [30]. SP measurement requires business managers to define the goals and criteria of what is understood by corporate sustainability performance with stakeholders and to establish a measurement and reporting system that supports the management and communication of those indicators [32]. Stakeholders should participate (directly or indirectly) in the definition of the indicators by adopting disclosure protocols, such as those outlined in the GRI, or through engagement processes [2]. The stakeholder engagement and participatory processes should, in fact, produce goals that are jointly derived, and sustainability reporting should help to collect, classify, analyze, and compare performance targets to those goals-to develop improvement plans that move the company toward sustainability accordingly [26].

Despite the importance of building a corporate sustainability image and promoting external sustainability reporting, scholars highlight that the development of management solutions to systematically follow the integration of sustainability into business strategy is still an issue [93,94]. Firms that claim to be sustainable should have a performance measurement system (PMS) that measures SP, since what cannot be measured cannot be managed $[95,96]$.

\subsection{Integration of Impact and Accountability}

The aforementioned critical aspect has brought about the convergence of two major topics which have become of interest both for academics and for business: social impact assessment (SIA) and the integrative management of sustainability performance. The latter is conceived to be a management tool linking business strategy and sustainability communications and reporting with performance management [32] through sustainable management accounting systems (SMASs). The first, as a measurement tool, incorporates social and environmental dimensions of sustainability in programs and projects [9]. Companies have begun to assess, manage, and monitor the social impacts that occur during project implementation to improve their internal strategies and to respond proactively to change [23,97-100]. Miller et al. [101] developed a framework based on five social dimensions that enable the identification, quantification, and comparability of social impact reporting and the identification of measurement tools to link SIA to CSR and to aid in the decision-making process. MASs partner in management decision-making in the same way, devising management tools and providing expertise in financial reporting and in control functions to assist in the formulation and implementation of an organization's strategy through balanced scorecards and measurement systems. However, a lack of integration between financial and nonfinancial goals and between SP indicators and strategic performance measurement systems remains [102].

To promote corporate SP means that sustainable development challenges must be incorporated [103,104] through operational practices [105] and business strategy [106]. The internal context that is needed to facilitate this process includes the integration of sustainability into strategic plans [107]; a formal declaration of the importance of sustainability to the firm [108]; and corporate governance and top management support [109-111], including a formal organizational policy [112], commitment to ethics [113], and a shared organizational culture [114].

\subsection{A Hybrid Solution: Benefit Corporations}

Several publications deal with the incorporation of sustainability into specific aspects of business [31], but they consider a single measure as a technocratic illusion, no matter how sophisticated it might be [26].

Meanwhile, Certified B Corps and Benefit Corporations offer a comprehensive measure that is inclusive of legal framework, certification, and rating standards. Through their assessment, the BIA, they have come up with a unique form of measurement which also functions as a guidance for management and as a standard for reporting that is integrated into their performance 
management system. The most effective corporate structure for scaling SP, in fact, seems to be the Benefit Corporation.

Benefit Corporations are for-profit companies that are committed to creating a benefit in addition to their for-profit motive [15]. The Benefit Act introduced by Maryland in 2010 gives directors and officers the legal protection to pursue a public benefit while expanding the obligations of boards, requiring them to consider environmental and social factors as well as the financial interests of shareholders [115]. In states and countries where the law is still not active, B Lab, a third party such as the U.S. Green Building Council, Underwriters Laboratory, Green Seal, or Global Reporting Initiative is present with its certification process [13].

Although their goal remains the same-using business as a force for good [21] - these two phenomena are separate: The Benefit Corporation status is a legal form of a corporation, while the $B$ Corp B Lab certification is a seal of fitness to the standards [15]. To become certified B Corps, companies have to achieve a score of 80 or above (which indicates value creation on top of profits) on the BIA [15]. The process involves inserting company data into the algorithm developed by B Labs' standards advisory council, a committee of independent members-respected in the field for their wisdom and with full industry or stakeholder expertise that adequately represents the diverse interests covered by the assessment-that holds itself above B Lab [116].

The BIA, an evolution of the SIA utilized to rate projects and as a B Corp index [117], measures impact on the following areas: workers, community, environment, customers, and governance. These areas, evaluated through questions, weighted averages, and calculations, consider the impact that the company may generate, the standards and certifications it has obtained, implemented in-house practices, community involvement, and value chain activities. Once the process evaluates the general impact of the business, the company that completes the assessment process (which lasts about six weeks) can add the B Corp certification to its products and website. Results can also be utilized to help prepare the annual Benefit Report, which Benefit Corporations are required to make available to the public (except in Delaware), as the BIA is also one of the third-party standards that meets the statutory requirements for such a report [118]. Lastly, the B Corp Benchmarks can be used to compare and improve a company's social and environmental performance.

In this context, the goal of the present exploratory research is to investigate the corporate performance measurement systems put in place by Benefit Corporations and to analyze the sustainability indicators utilized in the BIA assessment process, evaluating the level of integration of such indicators.

\section{Description of Case Study Methodology}

Given the lack of a research body on sustainable performance management in Benefit Corporations, exploratory research was chosen to develop new insights [119]. The study, mainly descriptive [120-122], was based on an exploratory case-based analysis. Eisenhardt and Graebner [123] find this method particularly useful in new research areas, or in situations in which researchers need to address "how" and "why" questions [123,124].

A literature review was performed to analyze the correlations among the main themes of the research. The literature review highlighted that single or multiple in-depth case studies were most often used when studying performance management, accounting systems, and CSR reporting. In Table 3 below is a summary of the primary literature in line with the research objective. 
Table 3. Content and case-based study literature when studying PMS, management accounting system (MAS), and CSR reporting.

\begin{tabular}{|c|c|c|}
\hline Theme & Objective & Number of Case Studies \\
\hline PMS [31] & $\begin{array}{l}\text { The different case studies helped to provide an } \\
\text { understanding of how companies integrate } \\
\text { sustainability into their pre-existing corporate PMS. }\end{array}$ & Five cross-sector case studies \\
\hline MAS/SP [32] & $\begin{array}{l}\text { The one-year case study helped to define the } \\
\text { importance of the SBSC as a strategic management } \\
\text { approach, outlining its importance as a } \\
\text { measurement, communication, and reporting tool. }\end{array}$ & $\begin{array}{l}\text { An extended single case } \\
\text { study carried out over a year }\end{array}$ \\
\hline PMS [2] & $\begin{array}{c}\text { The case study in a highly regulated specific sector } \\
\text { pinpointed how a multicriteria model that } \\
\text { considers the TBL framework helps corporate } \\
\text { decision-making. }\end{array}$ & $\begin{array}{l}\text { An extended single case } \\
\text { study carried out in a highly } \\
\text { regulated sector }\end{array}$ \\
\hline CSR Reporting [3] & $\begin{array}{l}\text { The cross-case study analysis was able to highlight } \\
\text { best practices on how companies manage their } \\
\text { CSR reporting. }\end{array}$ & Six cross-sector case studies \\
\hline $\begin{array}{l}\text { CSR Reporting } \\
\text { PMS [87] }\end{array}$ & $\begin{array}{l}\text { The content analysis helped to evaluate the } \\
\text { communication methods used on websites and in } \\
\text { CSR sustainability reports and how they were } \\
\text { utilized as a managerial tool. }\end{array}$ & $\begin{array}{l}\text { Content analysis of websites } \\
\text { and reports published online } \\
\text { by } 150 \text { top hotels worldwide }\end{array}$ \\
\hline $\begin{array}{l}\text { CSR Reporting } \\
\text { PMS [125] }\end{array}$ & $\begin{array}{c}\text { The analyzed case studies helped to investigate } \\
\text { whether firms that were rated good, mixed, or poor } \\
\text { in their environmental impact had better } \\
\text { disclosure policies. }\end{array}$ & Fifty-one U.S. firms \\
\hline
\end{tabular}

Academic research includes the sustainability disclosure of companies [125], corporate websites [87], and interviews [3,31]. All were deemed as valuable resources when studying the research topic.

Based on Eisenhardt's [121] recommendation to use from four to ten cases, sampling was done by selecting all the small- and medium-sized certified Benefit Corporations stratified by country. Italy was chosen since it was the first European country to produce benefit corporation legislation (in 2016) after the U.S. We selected the entire Italian sample of 20 B Corps; we then excluded 5 that were not also certified Benefit Corporations and a further 3 that were were not SMEs, obtaining a sample of 12 smalland medium-sized certified Benefit Corporations. All the companies in the sample were contacted for the interview and seven replied. The analysis was performed from April 2017 to February 2018. Each single company was considered as an analysis unit [126].

The information was gathered using multiple sources of secondary information (e.g., corporate documents, websites, and press releases, which provide more accurate and unbiased information) and contextualized with interview questions to the top management. Research questions were elaborated by analyzing the literature review and secondary information.

The interviews and documents were analyzed qualitatively through iterative coding into the themes formalized by the research objectives [31] to unravel new concepts from the data [127,128]. Similarly, document analysis was performed. This approach is well suited for in-depth single case studies [129]. The qualitative data analysis began with a within-case analysis, exploring the uniqueness of each case, followed by a cross-case analysis [130], since in multiple cases, the study should examine similarities and differences across cases.

Results were then interpreted and compared with those in the literature [126], facilitating theory building [130]. The interviewed companies are mentioned with their actual name and details (Table 4). 
Table 4. The selected sample.

\begin{tabular}{|c|c|c|c|}
\hline Company & $\begin{array}{c}\text { Year of } \\
\text { Foundation }\end{array}$ & Sector & About \\
\hline D-Orbit Srl & 2011 & $\begin{array}{l}\text { Business Products and } \\
\text { Services }\end{array}$ & $\begin{array}{l}\text { D-Orbit develops smart satellite } \\
\text { disposal systems for reducing } \\
\text { man-created debris in orbital space }\end{array}$ \\
\hline EXE.it Srl Sb & 1988 & $\begin{array}{l}\text { Energy and Environmental } \\
\text { Services }\end{array}$ & $\begin{array}{l}\text { EXE built the first zero-emission data } \\
\text { center in southern Europe that was } \mathrm{CO}_{2} \\
\text { emission free }\end{array}$ \\
\hline Facile Aiuto & 2013 & Health and Human Services & $\begin{array}{l}\text { Facile Aiuto is a facilitator whose aim is } \\
\text { realizing innovative projects and } \\
\text { services dedicated to health promotion }\end{array}$ \\
\hline Mondora srl & 2002 & $\begin{array}{l}\text { Business Products and } \\
\text { Services }\end{array}$ & $\begin{array}{l}\text { Mondora is a software and advisory } \\
\text { company that promotes holacracy, puts } \\
\text { people in the center, and supports its } \\
\text { community }\end{array}$ \\
\hline Nativa & 2012 & $\begin{array}{l}\text { Business Products and } \\
\text { Services }\end{array}$ & $\begin{array}{c}\text { Nativa is a re-design company creating } \\
\text { a positive impact on people and planet, } \\
\text { thus growing happiness }\end{array}$ \\
\hline Right Hub & 2015 & $\begin{array}{l}\text { Business Products and } \\
\text { Services }\end{array}$ & $\begin{array}{l}\text { Right Hub works on procurement, } \\
\text { logistics, marketing, and sustainable } \\
\text { supply chains, the missing link between } \\
\text { non-profit suppliers and for-profit } \\
\text { companies }\end{array}$ \\
\hline $\begin{array}{l}\text { Cooperativa } \\
\text { Insieme }\end{array}$ & 2010 & $\begin{array}{l}\text { Business Products and } \\
\text { Services }\end{array}$ & $\begin{array}{l}\text { Insieme is a cooperative in which } \\
\text { customers associate to aggregate their } \\
\text { insurance needs, adhering to shared } \\
\text { protocols centered on ethics and } \\
\text { sustainable development. }\end{array}$ \\
\hline
\end{tabular}

Finally, the cross-case report was written and is presented herein.

\section{Results of Analysis}

This paper is a first exploration of how Benefit Corporations integrate sustainability practices into their performance management system. Knowledge about the management of CSR activities is critical for understanding of the integration of social value at large. Using a qualitative research design, the internal factors that are associated with the integration of the benefit impact assessment indicators of seven Italian small- and medium-sized certified Benefit Corporations were examined. Table 4 gives a description of the selected sample and its social value.

During semistructured interviews with benefit impact managers, CEOs, and business developers, what emerged was that programming and control structures, systems, and processes by which sustainability is managed varied across companies. Despite this heterogeneity in internal factors, some notable patterns of internal management were uncovered across companies, which resulted in a typology of companies [3]. Figure 1 summarizes the different types. 


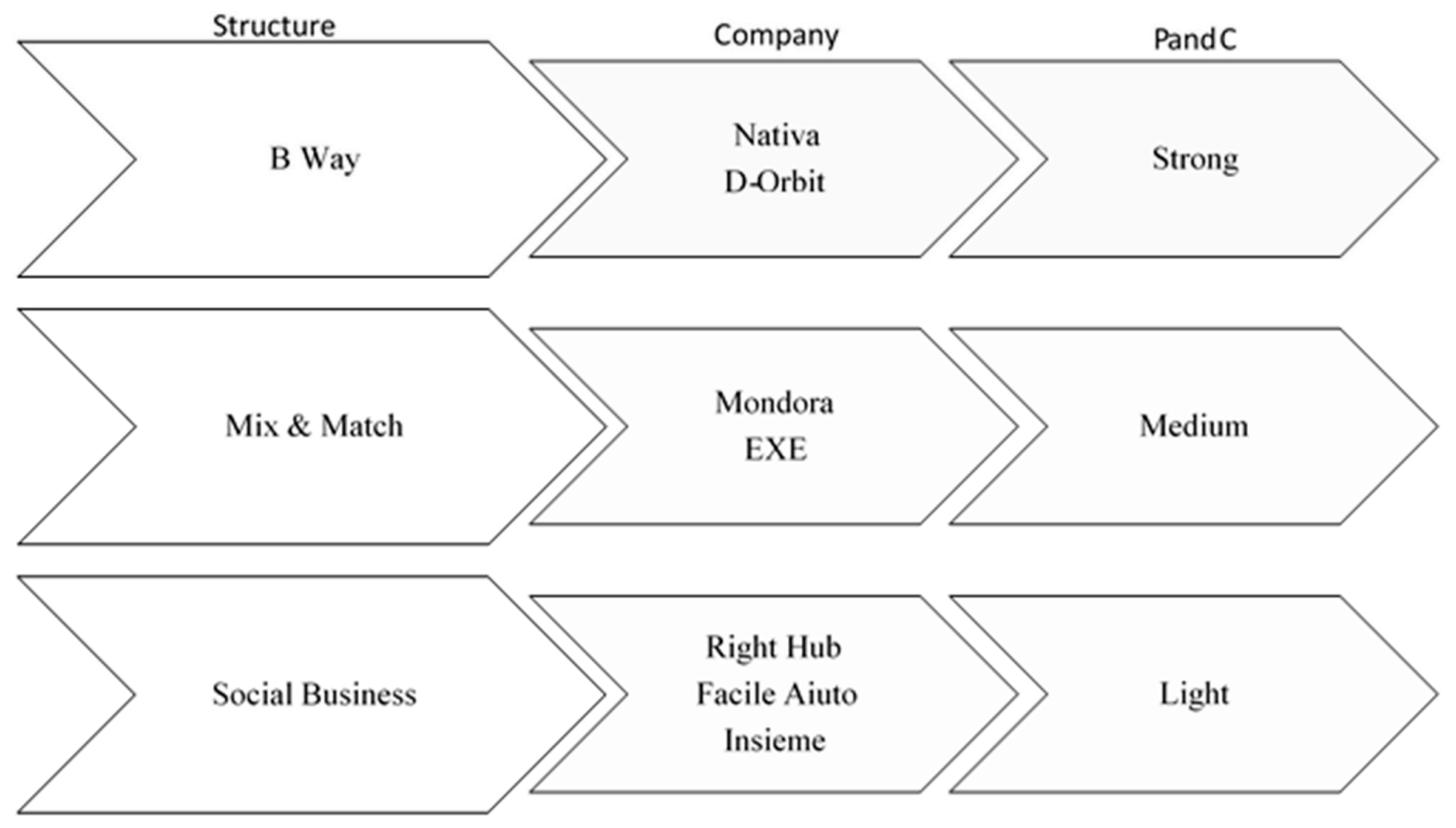

Figure 1. Business model and levels of implementation of benefit impact assessment (BIA)-guided sustainability indicators in the analyzed B Corps programming and control structures (PandC).

The first type of company, labeled "B Way", is characterized by the systematic integration of CSR into business operations. Drawing from the typology elaborated by Molteni and Lucchini [131] to portray the different approaches of Italian firms toward CSR, they can be considered as "cohesive firms." The companies that followed the B Way demonstrated a business orientation that integrated economic, social, and environmental goals into everyday decision-making. They also portrayed a high level of formalization when it came to reporting. Nativa was structured from the beginning as a Benefit Corporation; it was the first Benefit Corporation in Italy, and it has a mission to promote and accelerate this new paradigm, making Italy a model for sustainable innovation. Nativa also played a crucial role in conceiving and developing Italian legislation on Benefit Corporations. As a consulting company, they support other B Corporations: Mondora, which is in contact with them and which obtained the certification idea from Eric Ezechieli, one of Nativa's founders, has a much more structured approach than the other analyzed B Corps. The same was evident from the D-Orbit case analysis: the companies that utilized consulting support achieved better results and portrayed a better structure.

The second type of company was structured as social enterprises (SE), and they maintained their SE business model. They were thus characterized by a lack of formal organization, slim to no reporting, and decoupled CSR. Although these companies acknowledged the importance of structures, systems, and processes for CSR, they still had not developed and installed formal CSR practices. They showed an inclination toward CSR strategies, but their activities were still separate from everyday business, and this was considered to be mainly a communication issue. Size proved to have had an impact on the decision to be more flexible and less formal [132-134]. Furthermore, stakeholders trusted the social mission and were not looking for extra proof.

"We are small; we have four employees plus some external collaborators, depending on the projects. So, let's say that the issue of sustainability reporting has not, for now, been taken into account just because of our size. I did not consider it essential at this stage of the company's growth", says Luca Guzzabocca, CEO of Right Hub. Moreover, to tell you the truth, no customer, both profit and non-profit, of the ones we collaborate with has ever asked us for specific accountability on our social impact" [135].

Companies in the last category, "mix and match", had a mixed approach and combined integrated CSR with informal structures, ad hoc strategies, and systems. Ultimate performance was essential, and reporting was the consequence of this orientation, that is, informing stakeholders. 
"We communicate through a blog where we write nothing about technology or about the work we do. We write about all those things we call benefit projects, which are outside the box." Kirsten Ruffoni, Mondora's benefit impact manager, curates the blog herself, together with top management.

In general, Benefit Corporations in Italy maintained the same tiers secteur characteristics, as Jacques Delors defined it in 1979—an active social mission and a nonformal structure-and they are an example of the non-profit sector moving towards for-profit practices. The BIA indicators were fully integrated, but without a structural approach. They seemed to have skipped a step in moving from CSR to Benefit, and this change in paradigm was voluntary.

As Paolo Di Cesare, co-founder of Nativa, puts it: "We already use the most advanced and robust measuring instruments. We are open to new inputs, but I doubt that the concept of CSR can bring new ideas. It has the historical merit of getting companies out of pure compliance to new areas of identity that have raised the burden of responsibility for doing business. But now we have to look at new frontiers and make sure that these develop as quickly as possible. Today the BIA is used by more than 63,000 companies in the world, and it is expected to reach 100,000 by 2019 . The concreteness of the B Corp concept is to extend beyond its commitment on paper. Businesses find it useful to measure impact and discover areas of improvement, and hence embrace the movement" [136].

From this perspective, the concept of CSR could be obsolete and the tools available no longer adequate to achieve a sustainable for-profit and for-purpose model. CSR practices are seen by Benefit Corporations as a voluntary, nonbinding frame that is no longer able to support the prosocial identity [137] businesses that entrepreneurs want to achieve and with which stakeholders can identify.

Contrary to the literature that states that external stakeholder pressure has significant impacts on corporate social responsibility implementation [138], and that companies may invest in philanthropic activities to improve external perceptions and influence external decision-makers that affect the company [139], Benefit Corporations had an internally driven proactive behavior. Their approach to stakeholders was thus coherent with their mission and drive and inserting the BIA into their programming and control structure was a logical consequence. Thus, to legitimize their social value, Italian-certified Benefit Corporations integrated BIA-guided sustainability measures into their day-to-day activities.

\section{Discussion}

We can distinguish between two general approaches to assess impact [140]: a project-based analysis of specific programs, as per the SIA methodology, and a standardized analysis of the social orientation of business models, as per the BIA methodology. Standardized tools to measure impact include the United Nations' Social Development Goals, the Impact Reporting and Investment Standards (IRIS), the Global Impact Investing Report System (GIIRS), and, as mentioned, the B Lab Certification [140]. The BIA has recently been adopted by the United Nations to help companies evaluate their performance against the UN's Social Development Goals, so an integration of these two standards will soon be available.

What emerges from the data analyzed, taking into consideration B Lab Certified B Corps, is that the prosocial value [137] of B Corps functions as a driver and motivates the assessment of the common benefit produced by Benefit Corporations. BIA results are used to support internal decision-making by top management and employees, and BIA-guided indicators are integrated into the company planning and control systems. Although, as we were able to see in the results, the approach differs, they are all either integrated, almost integrated, or getting there. The B Way companies are at full integration levels; the Social Businesses are trying to keep up to par, and they tend to represent the average Italian $\mathrm{SME}$; and finally, the mix and match are in between.

The Benefit Impact Assessment and the B Lab key performance indicators could potentially better fit the prosocial need that has been witnessed in these past years, and the Italian case study shows a movement in that direction. The BIA though still leaves some doubts in terms of accountability and 
comparability, as opposed to the more structured CSR indicators and reporting guidelines that are available. For now, the B Corp movement runs alongside existing models as a new paradigm.

The implications of this paper are twofold. On the one hand, the paper highlights the importance of integrating sustainability into performance management systems as guidance for management and as a standard for reporting, especially in companies with a strong prosocial value, such as Benefit Corporations. On the other hand, the SME Italian-certified Benefit Corporation sample underlines specific integration levels that are true for Italian B Corps, which can be used as a base point to study evolutions or pinpoint differences. This way, in the future, it may be possible to overcome the comparability limitations of the BIA, and measuring impact can itself be an essential management practice [140].

As for the limitations of the study, it must be acknowledged that the research focused solely on the correlations among measurement, management, and reporting in performance and management accounting systems and CSR because the literature was extensive. Moreover, although the entire Italian sample was contacted, only seven B Corps replied and were available for the interviews. Future research should extend the investigation to the entire sample of Italian-certified Benefit Corporations. Finally, qualitative studies should explore the effectiveness of the benefit impact assessment by studying the impact beneficiaries through questionnaires, one-to-one interviews, and focus groups.

Author Contributions: Conceptualization, G.N. and M.D.B.; Methodology, G.N. and M.D.B.; Validation, M.D.B.; Formal Analysis, G.N. and M.D.B.; Investigation, G.N.; Data Curation, G.N.; Writing-Original Draft Preparation, G.N. and M.D.B.; Writing-Review \& Editing, G.N.; Visualization, M.D.B.; Supervision, M.D.B.; Project Administration, M.D.B.; Funding Acquisition, M.D.B.

Funding: This research was funded by the Dipartimento di Economia, Società, Politica (DESP), University of Urbino Carlo Bo.

Acknowledgments: We would like to thank Armando Agulini for his help with the interviews and document analysis, Filippo Giordano and Laura Michelini for their help in elaborating the idea and Frances Fabian for her feedback. The paper was presented at the VII Management Control: Value Creation and Stakeholder Protection Conference in Cagliari in May 2018 and at the 7th Italian Conference on Social and Environmental Accounting Research-Accounting, Accountability and Society Conference in Urbino in September 2018. We are grateful for the precious feedback given by fellow researchers and chairs of our sessions, in particular Jesse Dillard.

Conflicts of Interest: The authors declare no conflict of interest.

\section{References}

1. Sustainability Performance Management: How CFOs can Unlock Value; Accenture: Dublin, Ireland, 2011.

2. Garcia, S.; Cintra, Y.; de Torres, R.C.S.R.; Lima, F.G. Corporate sustainability management: A proposed multi-criteria model to support balanced decision-making. J. Clean. Prod. 2016, 136, 181-196. [CrossRef]

3. Thijssens, T.; Bollen, L.; Hassink, H. Managing sustainability reporting: Many ways to publish exemplary reports. J. Clean. Prod. 2016, 136, 86-101. [CrossRef]

4. Cintra, Y.; Carter, D. Internalising sustainability: Reflections on management control in Brazil. Int. J. Strateg. Manag. 2012, 12, 108-125.

5. Alexander, J.; Brudney, J.L.; Yang, K. Introduction to the Symposium: Accountability and Performance Measurement: The Evolving Role of Nonprofits in the Hollow State. Nonprofit Volunt. Sect. Q. 2010, 39, 565-570. [CrossRef]

6. Mitchell, G.E. The Construct of Organizational Effectiveness: Perspectives from Leaders of International Nonprofits in the United States. Nonprofit Volunt. Sect. Q. 2013, 42, 324-345. [CrossRef]

7. Liket, K.C.; Maas, K. Nonprofit Organizational Effectiveness: Analysis of Best Practices. Nonprofit Volunt. Sect. Q. 2015, 44, 268-296. [CrossRef]

8. Report of the World Commission on Environment and Development: Our Common Future; United Nations: Geneva, Switzerland, 1987.

9. Grieco, C. Assessing Social Impact of Social Enterprises: Does One Size Really Fit All? Springer Briefs in Business; Springer: Cham, Switzerland, 2015; ISBN 978-3-319-15314-8. 
10. Dohrmann, S.; Raith, M.; Siebold, N. Monetizing Social Value Creation-A Business Model Approach. Entrep. Res. J. 2015, 5. [CrossRef]

11. Lisi, I.E. Il Sistema di Programmazione e Controllo della Sostenibilità Socio-Ambientale; Franco Angeli: Milan, Italy, 2018.

12. Il Testo di Legge sulle Società Benefit. 2015. Available online: http:/ / www.societabenefit.net/testo-di-legge/ (accessed on 7 November 2018).

13. Alcorn, S.; Alcorn, M. Benefit Corporations: A New Formula for Social Change; Associations Now: Washington, DC, USA, 2012.

14. Hiller, J.S. The Benefit Corporation and Corporate Social Responsibility. J. Bus. Ethics 2013, 118, $287-301$. [CrossRef]

15. Nicholas, A.J.; Sacco, S. People, Planet, Profit: Benefit and B Certified Corporations-Comprehension and Outlook of Business Students; Salve Regina University: Newport, RI, USA, 2017.

16. Castellani, G.; De Rossi, D.; Rampa, A. Le Società Benefit: La nuova prospettiva di una Corporate Social Responsability con Commitment; Fondazione Nazionale dei Commercialisti: Rome, Italy, 2016.

17. Nigri, G.; Michelini, L.; Grieco, C. Social Impact and Online Communication in B-Corps. Glob. J. Bus. Res. 2017, 11, 87-104.

18. Billis, D. (Ed.) Hybrid Organizations and the Third Sector: Challenges for Practice, Theory and Policy; Palgrave Macmillan: Basingstoke, UK; New York, NY, USA, 2010; ISBN 978-0-230-23463-5.

19. Hemphill, T.A.; Cullari, F. The Benefit Corporation: Corporate Governance and the For-profit Social Entrepreneur: The Benefit Corporation: Corporate Governance and the For-profit Social Entrepreneur. Bus. Soc. Rev. 2014, 119, 519-536. [CrossRef]

20. Wilburn, K.; Wilburn, R. The double bottom line: Profit and social benefit. Bus. Horiz. 2014, 57, 11-20. [CrossRef]

21. Honeyman, R. Il manuale delle B Corp. Usare il Business Come Forza Positiva; Bookabook: Milan, Italy, 2016.

22. McMullen, J.S.; Warnick, B.J. Should We Require Every New Venture to Be a Hybrid Organization?: Exploring the Limits of a World of Blended Value. J. Manag. Stud. 2016, 53, 630-662. [CrossRef]

23. Sedatole, K. The Effect of Measurement Alternatives on a Nonfinancial Quality Measure's Forward-Looking Properties. Account. Rev. 2003, 78, 555-580. [CrossRef]

24. Cinquini, L.; Norreklit, H. Editorial. "Management Control" Special Issue: Research perspectives in Performance Management. Manag. Control 2015, 5-12. [CrossRef]

25. Bassani, G.; Cattaneo, C. Performance Management Systems and Strategy: The state of the art in Italian journals. Manag. Control 2015, 13-40. [CrossRef]

26. Schaltegger, S.; Burritt, R.L. Sustainability accounting for companies: Catchphrase or decision support for business leaders? J. World Bus. 2010, 45, 375-384. [CrossRef]

27. Gray, R.; Kouhy, R.; Lavers, S. Corporate social and environmental reporting: A review of the literature and a longitudinal study of UK disclosure. Account. Auditing Account. J. 1995, 8, 47-77. [CrossRef]

28. Elkington, J.; Kreander, N.; Stibbard, H.; Elkington, J.; Kreander, N.; Stibbard, H. The third international survey on company environmental reporting: The 1997 benchmark survey. Greener Manag. Int. 1998, 21, 99-111.

29. Wagner, M.; Schaltegger, S. How does sustainability performance relate to and business competitiveness? Greener Manag. Int. 2003, 44, 5-16. [CrossRef]

30. Morioka, S.N.; de Carvalho, M.M. A systematic literature review towards a conceptual framework for integrating sustainability performance into business. J. Clean. Prod. 2016, 136, 134-146. [CrossRef]

31. Morioka, S.N.; Carvalho, M.M. Measuring sustainability in practice: Exploring the inclusion of sustainability into corporate performance systems in Brazilian case studies. J. Clean. Prod. 2016, 136, 123-133. [CrossRef]

32. Schaltegger, S.; Wagner, M. Integrative management of sustainability performance, measurement and reporting. Int. J. Account. Auditing Perform. Eval. 2006, 3, 1. [CrossRef]

33. Gray, R.; Javad, M.; Power, D.M.; Sinclair, C.D. Social and Environmental Disclosure and Corporate Characteristics: A Research Note and Extension. J. Bus. Financ. Account. 2001, 28, 327-356. [CrossRef]

34. Munda, G. Social multi-criteria evaluation for urban sustainability policies. Land Use Policy 2006, $23,86-94$. [CrossRef]

35. Krajnc, D.; Glavič, P. A model for integrated assessment of sustainable development. Resour. Conserv. Recycl. 2005, 43, 189-208. [CrossRef] 
36. Khalili, N.R.; Duecker, S. Application of multi-criteria decision analysis in design of sustainable environmental management system framework. J. Clean. Prod. 2013, 47, 188-198. [CrossRef]

37. Santoyo-Castelazo, E.; Azapagic, A. Sustainability assessment of energy systems: Integrating environmental, economic and social aspects. J. Clean. Prod. 2014, 80, 119-138. [CrossRef]

38. Bititci, U.; Garengo, P.; Dörfler, V.; Nudurupati, S. Performance Measurement: Challenges for Tomorrow*: Performance Measurement. Int. J. Manag. Rev. 2012, 14, 305-327. [CrossRef]

39. Franco-Santos, M.; Lucianetti, L.; Bourne, M. Contemporary performance measurement systems: A review of their consequences and a framework for research. Manag. Account. Res. 2012, 23, 79-119. [CrossRef]

40. Fiorentino, R.; Garzella, S.; Lamboglia, R.; Mancini, D. Strategie di sostenibilità: Dalle motivazioni ai sistemi di misurazione della performance. Manag. Control 2016, 115-142. [CrossRef]

41. Kaplan, R.S.; Norton, D.P. The strategy map: Guide to aligning intangible assets. Strategy Leadersh. 2004, 32 , 10-17. [CrossRef]

42. Kaplan, R.S.; Norton, D.P. The Balanced Scorecard: Translating Strategy into Action; McGraw Hill: New York, NY, USA, 1996.

43. Kaplan, R.S.; Norton, D.P. The Balanced Scorecard-Measures that drive performance. Harv. Bus. Rev. 1992, 70, 172-180.

44. Cameron, J. Social Accounting: A Practical Guide for Small Community Organisations and Enterprises; Centre for Urban and Regional Studies: Birmingham, UK, 2010.

45. Costa, E.; Pesci, C. Social impact measurement: Why do stakeholders matter? Sustain. Account. Manag. Policy J. 2016, 7, 99-124. [CrossRef]

46. Epstein, M.J. Making Sustainability Work Best Practices in Managing and Measuring Corporate Social, Environmental and Economic Impacts; Routledge: Milton, UK, 2018; ISBN 978-1-351-28011-2.

47. Olsen, S.; Galimidi, B. Managing Social and Environmental Impact: A New Discipline for a New Economy. Brown J. World Aff. 2009, 15, 43-56.

48. Montecchia, A.; Giordano, F.; Grieco, C. Communicating CSR: Integrated approach or Selfie? Evidence from the Milan Stock Exchange. J. Clean. Prod. 2016, 136, 42-52. [CrossRef]

49. Kates, W. What is sustainable development? Environ. Sci. Policy Sustain. Dev. 2005, 47, 8-21.

50. Frost, G.; Jones, S.; Loftus, J.; Laan, S. A Survey of Sustainability Reporting Practices of Australian Reporting Entities. Aust. Account. Rev. 2005, 15, 89-96. [CrossRef]

51. Isenmann, R.; Lenz, C. Customized corporate environmental reporting by internet-based push and pull technologies. Eco-Manag. Auditing 2001, 8, 100-110. [CrossRef]

52. Weil, W.B.; Winter-Watson, B. The Internet and Sustainability Reporting. In The Ecology of the New Economy: Sustainable Transformation of Global Information; Greenleaf Publishing Limited: London, UK, 2002; pp. 85-98. ISBN 978-1-909493-26-1.

53. De Burgos-Jiménez, J.; Cano-Guillén, C.J.; Céspedes-Lorente, J.J. Planning and Control of Environmental Performance in Hotels. J. Sustain. Tourism 2002, 10, 207-221. [CrossRef]

54. Perrini, F.; Tencati, A. Sustainability and stakeholder management: The need for new corporate performance evaluation and reporting systems. Bus. Strategy Environ. 2006, 15, 296-308. [CrossRef]

55. Perrini, F.; Russo, A.; Tencati, A. CSR Strategies of SMEs and Large Firms. Evidence from Italy. J. Bus. Ethics 2007, 74, 285-300. [CrossRef]

56. Elena Windolph, S.; Schaltegger, S.; Herzig, C. Implementing corporate sustainability: What drives the application of sustainability management tools in Germany? Sustain. Account. Manag. Policy J. 2014, 5, 378-404. [CrossRef]

57. Broccardo, L. Management Accounting System in Italian Smes: Some Evidences and Implications. Adv. Manag. Appl. Econ. 2014, 4, 1-16.

58. Schaltegger, S.; Bennett, M.; Burritt, R. (Eds.) Sustainability Accounting and Reporting. In Eco-Efficiency in Industry and Science; Springer: Dordrecht, The Netherlands, 2006; ISBN 978-1-4020-4079-5.

59. Kearney, R.; Berman, E.M. Public Sector Performance: Management, Motivation, and Measurement; Routledge: Boulder, CO, USA, 2018; ISBN 978-0-429-96651-4.

60. Lowe, E.A. On the Idea of a Management Control System: Integrating Accounting and Management Control. J. Manag. Stud. 1971, 8, 1-12. [CrossRef]

61. Lowe, E.A.; McInnes, J.M. Control in Socio-Economic Organizations: A Rationale for The Design of Management Control Systems, (Section I). J. Manag. Stud. 1971, 8, 213-227. [CrossRef] 
62. Higgins, C.; Coffey, B. Improving how sustainability reports drive change: A critical discourse analysis. J. Clean. Prod. 2016, 136, 18-29. [CrossRef]

63. Antolín-López, R.; Delgado-Ceballos, J.; Montiel, I. Deconstructing corporate sustainability: A comparison of different stakeholder metrics. J. Clean. Prod. 2016, 136, 5-17. [CrossRef]

64. Ng, A.W.; Nathwani, J. Sustainability performance disclosures: The case of independent power producers. Renew. Sustain. Energy Rev. 2012, 16, 1940-1948. [CrossRef]

65. Rodríguez-Rodríguez, D.; Martínez-Vega, J.; Echavarría, P. A twenty year GIS-based assessment of environmental sustainability of land use changes in and around protected areas of a fast developing country: Spain. Int. J. Appl. Earth Obs. Geoinf. 2019, 74, 169-179. [CrossRef]

66. Rodriguez, M.A.; Ricart, J.E.; Sanchez, P. Sustainable Development and the Sustainability of Competitive Advantage: A Dynamic and Sustainable View of the Firm. Creat. Innovat. Manag. 2002, 11, 135-146. [CrossRef]

67. GRI 2013. Available online: https://www.globalreporting.org/information/news-and-press-center/ newsarchive/Pages/2013.aspx (accessed on 7 November 2018).

68. Sartori, S.; Latronico, F.; Campos, L. Sustainability and sustainable development: A taxonomy in the field of literature. Ambient. Soc. 2014, 17, 1-22. [CrossRef]

69. Moore, J.E.; Mascarenhas, A.; Bain, J.; Straus, S.E. Developing a comprehensive definition of sustainability. Implement. Sci. 2017, 12. [CrossRef] [PubMed]

70. GRI 2018. Available online: https://www.globalreporting.org/information/news-and-press-center/ newsarchive/Pages/2018.aspx (accessed on 7 November 2018).

71. Nachhaltig Managen mit der Balanced Scorecard: Konzept und Fallstudien; Schaltegger, S.; Dyllick, T. (Eds.) 1. Aufl.; Gabler: Wiesbaden, Germany, 2002; ISBN 978-3-409-12080-7.

72. Akkermans, H.A.; van Oorschot, K.E. Relevance Assumed: A Case Study of Balanced Scorecard Development Using System Dynamics. In System Dynamics; Kunc, M., Ed.; Palgrave Macmillan: London, UK, 2018; pp. 107-132. ISBN 978-1-349-95256-4.

73. Möller, A.; Schaltegger, S. The Sustainability Balanced Scorecard as a Framework for Eco-efficiency Analysis. J. Ind. Ecol. 2005, 9, 73-83. [CrossRef]

74. Bice, S. Bridging corporate social responsibility and social impact assessment. Impact Assess. Proj. Apprais. 2015, 33, 160-166. [CrossRef]

75. Hauser, J.; Katz, G. Metrics: You are what you measure! Eur. Manag. J. 1998, 16, 517-528. [CrossRef]

76. Vergragt, P.J.; Quist, J. Backcasting for sustainability: Introduction to the special issue. Technol. Forecast. Soc. Chang. 2011, 78, 747-755. [CrossRef]

77. Robinson, J.; Burch, S.; Talwar, S.; O'Shea, M.; Walsh, M. Envisioning sustainability: Recent progress in the use of participatory backcasting approaches for sustainability research. Technol. Forecast. Soc. Chang. 2011, 78, 756-768. [CrossRef]

78. Veleva, V.; Ellenbecker, M. Indicators of sustainable production: Framework and methodology. J. Clean. Prod. 2001, 9, 519-549. [CrossRef]

79. Kaplan, R.S. Conceptual Foundations of the Balanced Scorecard. In Handbooks of Management Accounting Research; Elsevier: Amsterdam, The Netherlands, 2009; Volume 3, pp. 1253-1269, ISBN 978-0-08-055450-1.

80. Searcy, V.; Lipps, A. The Effectiveness of Seeking Safety on Reducing PTSD Symptoms in Clients Receiving Substance Dependence Treatment. Alcohol. Treat. Q. 2012, 30, 238-255. [CrossRef]

81. Mouchamps, H. Weighing elephants with kitchen scales: The relevance of traditional performance measurement tools for social enterprises. Int. J. Prod. Perform. Manag. 2014, 63, 727-745. [CrossRef]

82. Orlitzky, M.; Swanson, D.L. Assessing Stakeholder Satisfaction: Toward a Supplemental Measure of Corporate Social Performance as Reputation. Corp. Reput. Rev. 2012, 15, 119-137. [CrossRef]

83. Keeble, J.J.; Topiol, S.; Berkeley, S. Using Indicators to Measure Sustainability Performance at a Corporate and Project Level. J. Bus. Ethics 2003, 44, 149-158. [CrossRef]

84. Hussain, N.; Rigoni, U.; Orij, R.P. Corporate Governance and Sustainability Performance: Analysis of Triple Bottom Line Performance. J. Bus. Ethics 2018, 149, 411-432. [CrossRef]

85. Canneva, G.; Guérin-Schneider, L. La construction des indicateurs de performance des services d'eau en France: Mesurer le développement durable? Nat. Sci. Soc. 2011, 19, 213-223. [CrossRef] 
86. Zaman Mir, M.; Shiraz Rahaman, A. In pursuit of environmental excellence: A stakeholder analysis of the environmental management strategies and performance of an Australian energy company. Account. Auditing Account. J. 2011, 24, 848-878. [CrossRef]

87. de Grosbois, D. Corporate social responsibility reporting by the global hotel industry: Commitment, initiatives and performance. Int. J. Hosp. Manag. 2012, 31, 896-905. [CrossRef]

88. Monsma, D.; Buckley, J. Non-Financial Corporate Performance: The Material Edges of Social and Environmental Disclosure. Univ. Balt. J. Environ. Law 2004, 151-203.

89. Latridis, G.E. Environmental disclosure quality: Evidence on environmental performance, corporate governance and value relevance. Emerg. Mark. Rev. 2013, 14, 55-75. [CrossRef]

90. Cormier, D.; Ledoux, M.; Magnan, M. The informational contribution of social and environmental disclosures for investors. Manag. Decis. 2011, 49, 1276-1304. [CrossRef]

91. Meijer, M.-M.; Schuyt, T. Corporate Social Performance as a Bottom Line for Consumers. Bus. Soc. 2005, 44, 442-461. [CrossRef]

92. Islam, M.A.; Deegan, C. Media pressures and corporate disclosure of social responsibility performance information: A study of two global clothing and sports retail companies. Account. Bus. Res. 2010, 40, 131-148. [CrossRef]

93. Bettiol, M.; De Marchi, V.; Di Maria, E.; Miceli, S. Economic, Social and Environmental Upgrading in Value Chains: Social Entrepreneurship and the Role of Emerging Economy Lead Firms 2011. Available online: http:/ / www.risingpowers.net/wp-content/uploads/2017/03/RisingPowers_WP4_Bettiol-et-al.pdf (accessed on 27 November 2018).

94. Gond, J.-P.; Grubnic, S.; Herzig, C.; Moon, J. Configuring management control systems: Theorizing the integration of strategy and sustainability. Manag. Account. Res. 2012, 23, 205-223. [CrossRef]

95. Cooper, S.M.; Owen, D.L. Corporate social reporting and stakeholder accountability: The missing link. Account. Organ. Soc. 2007, 32, 649-667. [CrossRef]

96. Ehrenfeld, J.R. Sustainability needs to be attained, not managed. Sustain. Sci. Pract. Policy 2008, 4, 1-3. [CrossRef]

97. Banker, R.D.; Potter, P.; Srinivasan, D. An Empirical Investigation of an Incentive Plan That Includes Nonfinancial Performance Measures. Account. Rev. 2000, 75, 65-92. [CrossRef]

98. Neely, A.; Mills, J.; Platts, K.; Richards, H.; Gregory, M.; Bourne, M.; Kennerley, M. Performance measurement system design: Developing and testing a process-based approach. Int. J. Oper. Prod. Manag. 2000, 20, 1119-1145. [CrossRef]

99. Franks, D.; Fidler, C.; Brereton, D.; Vanclay, F.; Clark, P. Leading Practice Strategies for Addressing the Social Impacts of Resource Developments; Centre for Social Responsibility in Mining, Sustainable Minerals Institute, The University of Queensland, and Department of Employment, Economic Development and Innovation, Queensland Government: Brisbane, Australia, 2009.

100. Buchan, D. New directions in social impact assessment: Conceptual and methodological advances. Impact Assess. Proj. Apprais. 2012, 30, 137-138. [CrossRef]

101. Miller, E.; Buys, L.; Summerville, J. Quantifying the social dimension of triple bottom line: Development of a framework and indicators to assess the social impact of organisations. Int. J. Bus. Gov. Ethics 2007, 3, 223. [CrossRef]

102. Schneider, A.; Meins, E. Two Dimensions of Corporate Sustainability Assessment: Towards a Comprehensive Framework: Two Dimensions of Corporate Sustainability Assessment. Bus. Strategy Environ. 2012, 21, 211-222. [CrossRef]

103. Crittenden, V.L.; Crittenden, W.F.; Ferrell, L.K.; Ferrell, O.C.; Pinney, C.C. Market-oriented sustainability: A conceptual framework and propositions. J. Acad. Mark. Sci. 2011, 39, 71-85. [CrossRef]

104. Savitz, A.W.; Weber, K. The Triple Bottom Line: How Today's Best-Run Companies are Achieving Economic, Social, and Environmental Success-and How You Can Too; Revised and Updated; Jossey-Bass, a Wiley Brand: San Francisco, CA, USA, 2014; ISBN 978-1-118-22622-3.

105. Labuschagne, C.; Brent, A.C.; van Erck, R.P.G. Assessing the sustainability performances of industries. Clean. Prod. 2005, 13, 373-385. [CrossRef]

106. Figge, F.; Hahn, T.; Schaltegger, S.; Wagner, M. The Sustainability Balanced Scorecard—Linking sustainability management to business strategy. Bus. Strategy Environ. 2002, 11, 269-284. [CrossRef] 
107. Klassen, R.D.; McLaughlin, C.P. The Impact of Environmental Management on Firm Performance. Manag. Sci. 1996, 42, 1199-1214. [CrossRef]

108. Melnyk, S. Assessing the impact of environmental management systems on corporate and environmental performance. J. Oper. Manag. 2003, 21, 329-351. [CrossRef]

109. Grosvold, J.; Hoejmose, S.U.; Roehrich, J.K. Squaring the circle: Management, measurement and performance of sustainability in supply chains. Supply Chain Manag. Int. J. 2014, 19, 292-305. [CrossRef]

110. Yongvanich, K.; Guthrie, J. An extended performance reporting framework for social and environmental accounting. Bus. Strategy Environ. 2006, 15, 309-321. [CrossRef]

111. Cohen, E. Benefit Expenses: How the Benefit Corporation's Social Purpose Changes the Ordinary and Necessary. William Mitchell Law Rev. 2012, 4, 269.

112. Griffith, A.; Bhutto, K. Improving environmental performance through integrated management systems (IMS) in the UK. Manag. Environ. Q. Int. J. 2008, 19, 565-578. [CrossRef]

113. Weaver, G.R.; TreviÑo, L.K.; Cochran, P.L. Integrated and Decoupled Corporate Social Performance: Management Commitments, External Pressures, and Corporate Ethics Practices. Acad. Manag. J. 1999, 42, 539-552. [CrossRef]

114. Sugita, M.; Takahashi, T. Influence of Corporate Culture on Environmental Management Performance: An Empirical Study of Japanese Firms: Influence of Corporate Culture on Environmental Management Performance. Corp. Soc. Responsib. Environ. Manag. 2015, 22, 182-192. [CrossRef]

115. Camm, E. Benefit Enforcement Proceedings for the Benefit Corporation-What are They and How Will They Work? Apex Law Group: Seattle, WA, USA, 2012.

116. Bauco, C.; Castellani, G.; De Rossi, D.; Magrassi, L. Società Benefit (Parte III); Fondazione Nazionale dei Commercialisti: Rome, Italy, 2017.

117. Nigri, G.; Michelini, L.; Grieco, C.; Iasevoli, G.B. Corps and their Social Impact Communication Strategy: Does the Talk Match the Walk? In Proceedings of the SIM Conference, New Orleans, LA, USA, 16-20 January 2016.

118. Benefit Corporation 2017. Available online: http://benefitcorp.net/businesses/benefit-corporationreporting-requirements (accessed on 7 November 2018).

119. Karwan, K.R.; Markland, R.E. Integrating service design principles and information technology to improve delivery and productivity in public sector operations: The case of the South Carolina DMV. J. Oper. Manag. 2006, 24, 347-362. [CrossRef]

120. Woodside, A.G.; Wilson, E.J. Case study research methods for theory building. J. Bus. Ind. Mark. 2003, 18, 493-508. [CrossRef]

121. Eisenhardt, K.M. Building Theories from Case Study Research. Acad. Manag. Rev. 1989, 14, 532. [CrossRef]

122. Ryan, B.; Scapens, R.; Theobald, M. Research Method \& Methodology in Finance E Accounting, 2nd ed.; Thomson: Stamford, CT, USA, 2002.

123. Eisenhardt, K.M.; Graebner, M.E. Theory Building From Cases: Opportunities And Challenges. Acad. Manag. J. 2007, 50, 25-32. [CrossRef]

124. Yin, R.K. Case Study Research: Design and Methods; Applied Social Research Methods Series; Sage Publications: Beverly Hills, CA, USA, 1990; Volume 5.

125. Hughes, S.B.; Anderson, A.; Golden, S. Corporate environmental disclosures: Are they useful in determining environmental performance? J. Account. Public Policy 2001, 20, 217-240. [CrossRef]

126. Yin, R.K. Case Study Research, 3rd ed.; Sage Publications: Newbury Park, CA, USA, 2003.

127. Gioia, D.A.; Corley, K.G.; Hamilton, A.L. Seeking Qualitative Rigor in Inductive Research: Notes on the Gioia Methodology. Organ. Res. Methods 2013, 16, 15-31. [CrossRef]

128. Glaser, B.G.; Strauss, A.L.; Paul, A.T. Grounded Theory: Strategien Qualitativer Forschung; Verlag Hans Huber-Programmbereich Gesundheit; 1. Nachdr. der 2., korrigierten Aufl.; Huber: Bern, Switzerland, 2008; ISBN 978-3-456-84212-7.

129. Bergh, D.D. (Ed.) Building Methodological Bridges. In Research Methodology in Strategy and Management; Emerald: Bingley, UK, 2011; ISBN 978-1-78052-026-1.

130. Huberman, A.; Miles, M. Qualitative Data Analysis: An Expanded Sourcebook, 2nd ed.; Sage Publications: Newbury Park, CA, USA, 1994.

131. Molteni, M.; Lucchini, M.; Unione Italiana delle Camere di Commercio, Industria, Artigianato e Agricoltura. Istituto per i valori d'impresa I Modelli di Responsabilità Sociale Nelle Imprese Italiane; FrancoAngeli: Milan, Italy, 2004. 
132. Murillo, D.; Lozano, J.M. SMEs and CSR: An Approach to CSR in their Own Words. J. Bus. Ethics 2006, 67, 227-240. [CrossRef]

133. Del Baldo, M. Stakeholder Management and CSR Approach in Italian "Territorial" Companies_Loccioni Group and the LOV_Land of Values 2012; University of Urbino Carlo Bo, Department of Economics, Society \& Politics: Urbino, Italy, 2012.

134. Looser, S.; Wehrmeyer, W. An Emerging Template of CSR in Switzerland. Corp. Ownersh. Control $2015,12$. [CrossRef]

135. Guzzabocca, L. Right Hub CEO 2017. Available online: http:/ /www.righthub.it/news-da-right-hub/19archivio-news-prima-pagina/16-il-progetto-right-hub (accessed on 7 November 2018).

136. Di Cesare, P. Nativa Co-Founder 2017. Available online: http://www.nativa.co.za/ (accessed on 7 November 2018).

137. Sharma, G.; Beveridge, A.J.; Haigh, N. A configural framework of practice change for B corporations. J. Bus. Ventur. 2018, 33, 207-224. [CrossRef]

138. Tian, Q.; Liu, Y.; Fan, J. The effects of external stakeholder pressure and ethical leadership on corporate social responsibility in China. J. Manag. Organ. 2015, 21, 388-410. [CrossRef]

139. Watts, R.L.; Zimmerman, G.L. Towards a Positive Theory of the Determination of Accounting Standard. Account. Rev. 1978, 53, 112-134.

140. Lazzarini, S.G. The measurement of social impact and opportunities for research in business administration. RAUSP Manag. J. 2018, 53, 134-137. [CrossRef]

(C) 2018 by the authors. Licensee MDPI, Basel, Switzerland. This article is an open access article distributed under the terms and conditions of the Creative Commons Attribution (CC BY) license (http:/ / creativecommons.org/licenses/by/4.0/). 